\title{
USO DE DETERGENTE À BASE DE CARQUEJA (BACCHARIS TRIMERA) COMO ALTERNATIVA PARA A LIMPEZA DE EQUIPAMENTOS DA ORDENHA
}

\author{
Anelise Kehl ${ }^{1}$, Divanilde Guerra ${ }^{2}$, Mastrangello Enivar Lanzanova ${ }^{2}$, Danni Maisa da Silva², Eduardo Lorensi de \\ Souza ${ }^{2}$, Robson Evaldo Gehlen Bohrer ${ }^{2}$, Talia Talita Senh ${ }^{3}$
}

\begin{abstract}
RESUMO - No Brasil a qualidade do leite vem se destacando em toda a cadeia produtiva, desde o produtor até o consumidor final. Desta forma, o objetivo do presente trabalho foi avaliar o uso do detergente alcalino e desinfetante à base de carqueja (Bacharis Trimera) como alternativa para a limpeza e sanitização diária dos equipamentos de ordenha em comparação ao detergente alcalino químico. O trabalho foi desenvolvido no Município de Bom Progresso/RS no período de julho de 2015 a agosto de 2016 em quatro propriedades rurais, sendo os agricultores denominados como Agricultor 1 (A1), Agricultor 2 (A2), Agricultor 3 (A3) e Agricultor Testemunha (T). A metodologia consistiu na avaliação da Contagem de Bactérias Total (CBT) do leite cru, a qual ocorreu pelo acompanhamento dos boletins de análise do leite fornecidos mensalmente pelas indústrias comerciantes. Como resultado, observou-se que o detergente à base de carqueja é um produto que possui propriedades de limpeza e sanitização. Sendo assim, o uso de detergente a base de carqueja na sanitização de equipamentos de ordenha permite a obtenção de CBT em níveis inferiores ao que preconiza a legislação vigente em relação à qualidade do leite.
\end{abstract}

Palavras chave: contagem bacteriana total, desinfetante, leite, sistemas de ordenha.

\section{USE OF DETERGENT BASED OF CARQUEJA (BACCHARIS TRIMERA) AS AN ALTERNATIVE FOR THE CLEANING OF MILKING EQUIPMENT}

\begin{abstract}
In Brazil, the quality of milk has been prominent throughout the production chain, from the producer to the final consumer. Thus, the objective of the present study was to evaluate the use of alkaline detergent and disinfectant based on carqueja (Bacharis Trimera) as an alternative for daily cleaning and sanitization of milking equipment compared to chemical alkaline detergent. The work was developed in the municipality of Bom Progresso / RS from July 2015 to August 2016 in four rural properties, with farmers named as Farmer 1 (A1), Farmer 2 (A2), Farmer 3 (A3) and Farmer Witness (T). The metodoly was the evaluating the Total Bacteria Count (TBC) of raw milk, which was monitored by the milk analysis bulletins provided monthly by the merchant industries. As a result, it has been observed that carqueja detergent is a product which has cleaning and sanitizing. Thus, the use of carqueja detergent in the sanitation of milking equipment allows to obtain TBC at lower levels than the current legislation regarding milk quality.
\end{abstract}

Keywords: disinfectant, milk, milking systems, total bacterial count.

\footnotetext{
${ }^{1}$ Especialista em Segurança Alimentar e Agroecologia. Extensionista Rural da Emater/RS-Ascar, Escritório Municipal de Bom Progresso, Avenida Castelo Branco, 820 - Bom Progresso-RS. CEP: 98575-000. Contato (55) 3528-6181.

2 Docente da Universidade Estadual do Rio Grande do Sul - UERGS. Unidade em Três Passos, Rua Cipriano Barata, 211 - Bairro Érico Veríssimo - Três Passos. CEP: 98600-000. Contato (55) 3522-2895.

3 Acadêmica do Curso de Bacharelado em Agronomia. UERGS. Unidade em Três Passos. E-mail para correspondência: divanilde-guerra@uergs.edu.br
} 


\section{INTRODUÇÃO}

No Brasil, a atividade leiteira é praticada em todas as regiões e está presente em aproximadamente 1,8 milhões de propriedades rurais, das quais $80 \%$ são unidades familiares de produção (Martins, 2004). Na região Noroeste do Rio Grande do Sul está realidade é muito semelhante a nacional, principalmente pelo grande número de agricultores familiares que obtém da cadeia leiteira a principal fonte de renda.

Em nível nacional, o Brasil vem aumentando significativamente a produção, pois conforme o Instituto Brasileiro de Geografia e Estatística (IBGE, 2014), a produção de leite foi de 35,2 bilhões de litros em 2014, o que significou um aumento de $2,7 \%$ em relação ao ano de 2013. A nível nacional, o estado do Rio Grande do Sul ocupa a segunda posição, ficando atrás somente do estado de Minas Gerais (IBGE, 2014).

Para Santos \& Fonseca (2007), um leite de boa qualidade deve apresentar baixa contagem bacteriana, ausência de microrganismos patogênicos e ausência de resíduos de medicamentos. Desta forma, o Ministério da Agricultura, Pecuária e Abastecimento (MAPA), estabeleceu através da Instrução Normativa $N^{\circ} 62$ (IN62), de 29 de dezembro de 2011, normas para regulamentar técnicas da produção de leite no Brasil, a fim de garantir um alimento de melhor qualidade para os consumidores (Brasil, 2011). Neste sentido, alguns cuidados são imprescindíveis, com destaque para o manejo e limpeza dos equipamentos, os quais posteriormente podem ser quantificados através da Contagem Bacteriana Total (CBT) que é o parâmetro utilizado com maior frequência para avaliar a qualidade do leite (Bava et al., 2009).

Segundo Andrade \& Pinto (1999), os equipamentos utilizados no processo de ordenha e resfriamento do leite requerem procedimentos contínuos de limpeza e desinfecção, pois podem acumular resíduos. Esses se depositam e podem abrigar microrganismos que se multiplicam e passam aos alimentos, contaminandoos. Portanto, a limpeza e a sanitização dos equipamentos requerem, além de cuidados básicos, a utilização de produtos para desinfecção e limpeza, os quais objetivam a eliminação da maior quantidade possível de resíduos de alimentos disponíveis para o desenvolvimento dos microrganismos (Hoffmann et al., 2002). Entre as substâncias utilizadas para a limpeza, encontram-se os detergentes de base alcalina ou ácida (Hoffmann et al., 2002). Porém, para Garcia \& Lunardi (2001), a aquisição destes produtos muitas vezes torna-se inviável economicamente, bem como, esses contribuem para a dependência externa do agricultor. Desta forma, a utilização de práticas sustentáveis, utilizando plantas medicinais, possibilita tornar a produção de leite mais rentável, com redução no uso de componentes químicos. Ainda conforme Garcia \& Lunardi, (2001) a natureza é rica em espécies que contêm diversos princípios ativos, que se usados corretamente, produzem efeitos benéficos a um custo reduzido.

Como alternativa aos insumos externos, que segundo Gliessman (2000) tornam o sistema dependente, surgem produtos alternativos como a Carqueja (Baccharis trimera) (Lorenzi \& Mattos, 2002). Esta é considerada uma planta com atividade antimicrobiana, sendo indicada como desinfetante e antisséptico biológico em ambientes de produção animal, podendo ser usada na higienização de forma contínua, mesmo naqueles de baixa condição econômica (Avancini et al., 2000). Extratos naturais de plantas como Baccharis trimera (carqueja), Eucalypys ssp (eucalipto) e Tagetes minuta (chinchilo) tiveram sua atividade antibacteriana testada e aprovada frente as bactérias Streptococcus agalactiae, Pseudomonas aerugiona e $S$. aures, apresentando, portanto, potencial para serem utilizados em situações-problema em que as bactérias estejam envolvidas (Schuch et al., 2008). Diante do exposto, este trabalho teve como objetivo avaliar o uso do detergente alcalino e desinfetante à base de carqueja como alternativa para limpeza e sanitização de equipamentos de ordenha e utensílios em substituição ao detergente alcalino químico através da avaliação da Contagem de Bactérias Total (CBT) do leite cru.

\section{MATERIAL E MÉTODOS}

O trabalho foi desenvolvido em quatro propriedades rurais no Município de Bom Progresso, Rio Grande do Sul (RS), sendo os agricultores denominados como Agricultor 1 (A1), Agricultor 2 (A2), Agricultor 3 (A3) e Agricultor Testemunha (T).

A propriedade do agricultor 1 (A1), tem em média 14 vacas em lactação, sendo todas das raças holandesa e Jersey. A alimentação é a base de pasto, silagem e ração. A sala de ordenha é canalizada, tendo ao todo um conjunto de quatro teteiras. A produção média de leite é de 4.430 litros no mês. A propriedade do agricultor 2 (A2) tem em média 22 vacas em lactação, sendo todas das raças holandesa e Jersey. A alimentação é a base de pasto, silagem e ração. A sala de ordenha é de balde ao pé, tendo ao todo um conjunto de duas teteiras. A produção média de leite é de 7.853 litros no mês. A propriedade do agricultor 3 (A3) tem em média 
25 vacas em lactação, sendo todas das raças holandesa e Jersey. A alimentação é a base de pasto, silagem e ração. A sala de ordenha é canalizada, tendo ao todo um conjunto de quatro teteiras. A produção média de leite é de 9.993 litros mensais. A propriedade do agricultor Testemunha (T) tem em média 18 vacas em lactação, sendo todas das raças holandesa e Jersey. A alimentação é a base de pasto, silagem e ração. A sala de ordenha é canalizada, tendo ao todo um conjunto de duas teteiras. A produção média de leite é de 6.285 litros mensais.

Nas quatro propriedades foram avaliados os resultados da contagem bacteriana, os quais foram obtidos através do acompanhamento dos boletins de análise do leite fornecido mensalmente aos agricultores pelas empresas recolhedoras de leite. $\mathrm{O}$ trabalho foi desenvolvido entre os meses de julho a dezembro de 2015, através da avalição dos resultados obtidos pela utilização de detergentes comerciais (para todos os produtores) e, de janeiro a agosto de 2016, através da avaliação da qualidade do leite produzido pelos agricultores A1, A2 e A3 com o detergente alternativo. Já o agricultor intitulado como testemunha (T) utilizou diariamente, durante todo o período de estudo, o detergente alcalino convencional da marca ALcalan Top, sendo recomendado ao mesmo que utilizasse o produto de acordo com a recomendação prescrita na embalagem, ou seja, 25 $\mathrm{ml}$ do produto para cada 10 litros de água.

A partir de janeiro de 2016 recomendou-se para os agricultores A1, A2 e A3, a utilização diária do detergente alcalino e desinfetante à base de carqueja, na quantidade de $80 \mathrm{ml}$ da solução, diluídos em 30 litros de água quente, em temperatura média de 70 a $75^{\circ} \mathrm{C}$ por dez minutos. Conforme Mendonça et al. (2012) o período de dez minutos possibilita a remoção dos resíduos de gordura do leite. Ainda, os quatro agricultores foram orientados a utilizar o detergente ácido comercial duas vezes na semana seguindo a recomendação do fabricante.

O detergente alcalino à base de carqueja foi desenvolvido utilizando extrato alcóolico da planta. O extrato para cada receita foi elaborado com 2 (dois) litros de álcool 92,8 e com 400 gramas de Baccharis trimera verde e picada sem os talos, ficando armazenado em vidro, acondicionado em local protegido da luz, por até 21 dias, sendo agitado diariamente (Velloso \& Peglow, 2003). Karam et al. (2013) citam as diversas propriedades fitoterápicas da carqueja já comprovadas cientificamente, entre elas as antissépticas e antibióticas. Folhas da planta foram colhidas nas estações do verão e outono, antes do início da floração, no interior do município de Bom Progresso/RS, distante de plantações que utilizassem agroquímicos.
Os agricultores avaliados neste estudo utilizaram manejos semelhantes, como: lavagem dos tetos dos animais antes da ordenha com água corrente e secagem com papel toalha. Após a ordenha, todos os animais passaram por um processo de pós-dipping com produto convencional, sendo depois, liberados para pastagem nos piquetes. Durante a ordenha, o leite foi transferido para o resfriador, e os equipamentos enxaguados com água em temperatura ambiente para retirar o resíduo de leite e posteriormente lavados com água quente e detergente durante 10 minutos.

Os dados referentes a qualidade do leite foram avaliados considerando os indicadores das análises microbiológicas feitas duas vezes por mês, ou seja, na primeira e segunda semana de cada mês pelos laboratórios das empresas que comercializam o leite. Estes dados foram informados mensalmente no Extrato de pagamento do leite e estão baseados no valor da CBT. Para a análise dos resultados foram considerados os valores numéricos encontrados em cada propriedade e em cada tratamento estudado, que foram organizados em figuras e comparados em valores percentuais.

\section{RESULTADOS E DISCUSSÃO}

No presente trabalho a qualidade do leite foi avaliada através de análises de Contagem Bacteriana Total (CBT). Segundo Bava et al. (2009), os parâmetros para avaliar com maior frequência a qualidade do leite são as análises de CBT. Conforme Cerqueira (2007), a qualidade microbiológica do leite cru resulta de um conjunto de fatores, como a saúde da glândula mamária, as condições de manejo do rebanho, da higiene na obtenção do leite, da sala e dos equipamentos e utensílios de ordenha, do estado de saúde do ordenhador e das condições de estocagem e transporte do leite enviado à indústria.

Com relação à contagem bacteriana total obtida através da utilização de detergentes comerciais convencionais em comparação a eficiência do detergente alcalino e desinfetante à base de carqueja os resultados obtidos com o Agricultor 1 (A1) podem ser visualizados na Figura 1.

Os resultados obtidos através da avaliação da qualidade do leite nos meses de julho a dezembro de 2015, ou seja, período em que o agricultor (A1) utilizou o detergente comercial variaram de 9.000 a 215.000 UFC/ml. Já os resultados obtidos através da avaliação da qualidade do leite nos meses de janeiro a agosto de 2016, ou seja, período em que o agricultor utilizou o detergente alcalino e desinfetante à base de carqueja variaram de 
18.000 a $196.000 \mathrm{UFC} / \mathrm{ml}$. Portanto os valores máximos de Contagem Bacteriana Total (CBT) obtidos em todos os meses de avaliação, independente do produto utilizado, ficaram bem abaixo do que preconiza a legislação vigente, que exige limite máximo de $300.000 \mathrm{UFC} / \mathrm{ml}$ de leite.

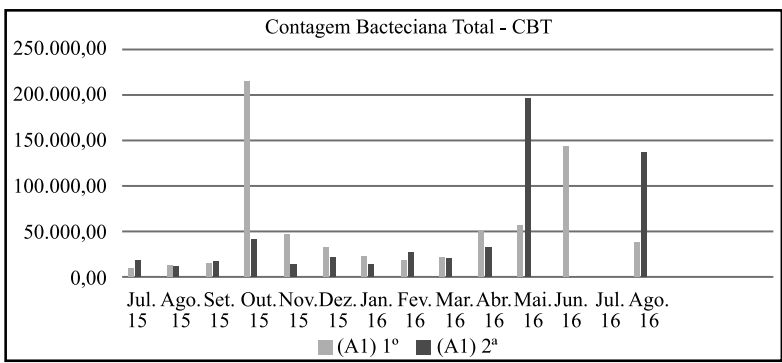

Figura 1 - Valores da contagem bacteriana (CBT) do agricultor 1 (A1) antes e depois de usar o detergente alcalino e desinfetante à base de carqueja. Os valores referem-se à $1^{\mathrm{a}}$ e $2^{\mathrm{a}}$ análise/mês. Os valores são medidos em UFC/ ML X 1000.

A normativa 62 que entraria em vigor em 30/06/2016, e que substituiria a Instrução Normativa N$^{\circ} 51$ de 2002, não foi implementada, mas sim, foi prorrogada no dia 03 de maio de 2016 por mais dois anos, sendo que está estabelece novos limites de qualidade previstos para o leite para as regiões Sul, Sudeste e Centro Oeste e prorroga para mais três anos para as regiões Norte e Nordeste. Assim que entrar em vigor os níveis de Contagem Bacteriana Total (CBT) serão reduzidos de $300 \mathrm{mil} \mathrm{UFC/ml} \mathrm{para} 100 \mathrm{mil}$ $\mathrm{UFC} / \mathrm{ml}$.

No presente trabalho, se os parâmetros da nova normativa estivessem em vigor, poderíamos observar na Figura 1 que com a utilização do detergente comercial, das 12 análises efetuadas, uma (8,33\%) apresentou valor superior a $100.000 \mathrm{UFC} / \mathrm{ml}$, porém após a utilização do detergente alcalino e desinfetante à base de carqueja, das 13 análises, três $(23,07 \%)$ apresentaram contagem bacteriana acima de $100.000 \mathrm{UFC} / \mathrm{ml}$, ou seja, demandando alguns cuidados nestes casos para manter a qualidade do leite dentro dos padrões estabelecidos.

Pode-se observar na Figura 1 que, a mesma possui somente uma informação quanto a análise no mês de junho e nenhuma informação do mês de julho. Isso se deve, pois, o agricultor alegou enfrentar problemas em relação à entrega do leite, sendo constatada através da análise de Crioscopia, que indica possível adição de água ao leite, que foram identificadas na segunda amostra de maio e na primeira amostra do mês de junho. Segundo informações do agricultor, o mesmo alega não ter adicionado água ao leite $\mathrm{e}$ não sabe quais foram as causas exatas de tal acontecimento. Uma das hipóteses para os resultados obtidos, pode ser a falta de cuidado com a drenagem da água após a limpeza das mangueiras da ordenhadeira, a qual, pode ter comprometido a qualidade final do produto, pois a utilização de água de má qualidade microbiológica pode contaminar equipamentos de ordenha e de resfriamento e, comprometer a qualidade do leite (Leite et al., 2003). Logo, os dados da Figura 1 indicam que neste período, os valores da CBT alteraram, dando indícios da possível contaminação do leite através de água contaminada adicionada ao leite. Após esse período, o agricultor (A1), passou a fornecer a produção para outra empresa, em busca de maior credibilidade e melhores preços, entretanto, a nova empresa comerciante, só forneceu o boletim mensal das análises no mês de agosto de 2016, o que prejudicou a verificação qualitativa até o final do referido estudo.

No mês de agosto o agricultor 1 (A1) utilizou o detergente alcalino, porém este foi manipulado sem o ingrediente carqueja, a fim de observar se a carqueja é desinfetante ou se a presença do álcool etílico na sua composição pode atuar na qualidade do leite. Os resultados obtidos foram de $38.000 \mathrm{UFC} / \mathrm{ml}$ de leite na primeira análise e $136.000 \mathrm{UFC} / \mathrm{ml}$ na segunda análise, ficando assim, com uma média mensal de $87.000 \mathrm{UFC} / \mathrm{ml}$ de leite. Segundo Brasil (2010), o álcool etílico age rapidamente sobre as bactérias vegetativas (inclusive microbactérias), vírus e fungos, mas não é esporicida. Santos et al. (2002) afirmam que o álcool possui propriedades microbicidas reconhecidamente eficazes para eliminar os germes mais frequentemente envolvidos nas infecções, se tornando então imprescindível na realização de ações simples de prevenção como a antissepsia e a desinfecção do ambiente. Além disso, possui baixo custo, fácil aplicabilidade e toxicidade reduzida.

Com relação a CBT obtida através da utilização de detergentes comerciais convencionais em relação à eficiência do detergente alcalino e desinfetante à base de carqueja os resultados obtidos com o Agricultor 2 (A2) podem ser visualizados na Figura 2.

Os resultados obtidos através da avaliação da qualidade do leite nos meses de julho a dezembro de 2015, ou seja, período em que o agricultor (A2) utilizou o detergente comercial variaram de 31.000 a 1.401 .000 UFC/ml. Já os resultados obtidos através da avaliação da qualidade do leite nos meses de janeiro a agosto de 2016, 
ou seja, período em que o agricultor utilizou o detergente alcalino e desinfetantes à base de carqueja variaram de 27.000 a $1.575 .000 \mathrm{UFC} / \mathrm{ml}$.

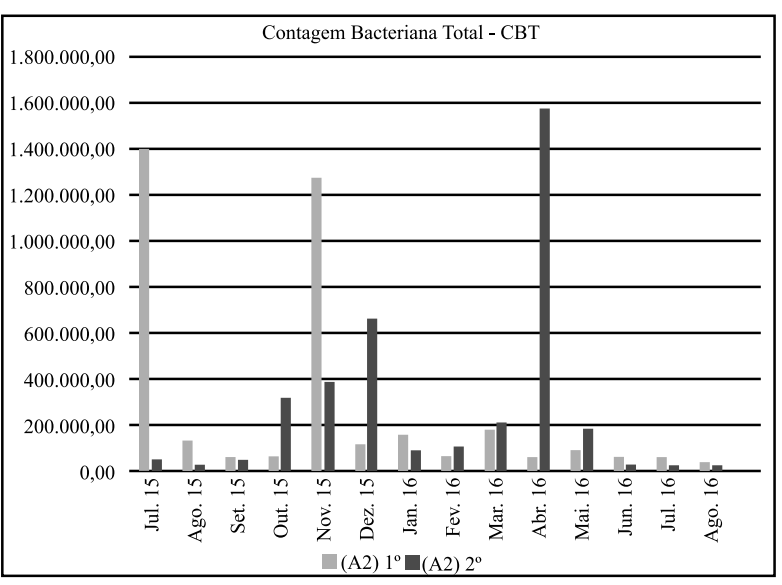

Figura 2 - Valores da contagem bacteriana (CBT) do agricultor (A2) antes e depois de usar o detergente alcalino e desinfetante à base de carqueja. Os valores referem-se à $1^{\mathrm{a}}$ e $2^{\mathrm{a}}$ análise/mês. Os valores são medidos em UFC/ ML X 1000

Na Figura 2 observa-se que das doze análises efetuadas nos meses de julho a dezembro de 2015, cinco $(41,66 \%)$ ficaram acima de $300.000 \mathrm{UFC} / \mathrm{ml}$ de leite. Já nos meses de janeiro a agosto de 2016, somente em uma das análises, a do mês de abril, ficou acima da média, representando $6,25 \%$ do total. Com a utilização do detergente comercial, das doze análises efetuadas, sete $(58,3 \%)$ apresentaram valores superiores a 100.000 $\mathrm{UFC} / \mathrm{ml}$, e que após a utilização do detergente alcalino e desinfetante à base de carqueja, seis $(37,5 \%)$ apresentaram contagem bacteriana acima de $100.000 \mathrm{UFC} / \mathrm{ml}$.

$\mathrm{Na}$ Figura 2 pode-se observar também que no mês de maio o agricultor A2, obteve um número elevado de CBT na segunda análise do referido mês, com os números chegando a 1.575.000,00 UFC/ml. O agricultor informou que sempre seguiu os mesmos procedimentos quanto a quantidade e temperatura de água, como também, quantidade do detergente alcalino para a limpeza diária. Considerando o período de início de inverno, buscouse informações quanto a precipitação no período em que foram feitas as análises e observou-se elevados níveis de precipitação. Segundo Bueno et al. (2008), o período de chuvas favorece o aumento da contaminação ambiental, o acúmulo de lama nas instalações e a maior ocorrência de tetos sujos no momento da ordenha, sendo que, os coeficientes de determinação das variações de CBT estão correlacionados de forma positiva com a umidade e a precipitação pluviométrica. Zucali et al. (2011) afirmam que a limpeza dos animais que chegam para serem ordenhados, influencia na qualidade do leite obtido e tem efeito significativo na contagem bacteriana.

Com relação à CBT obtida através da utilização de detergentes comerciais convencionais em relação à eficiência do detergente alcalino e desinfetante à base de carqueja os resultados obtidos com o Agricultor 3 (A3) podem ser visualizados na Figura 3.

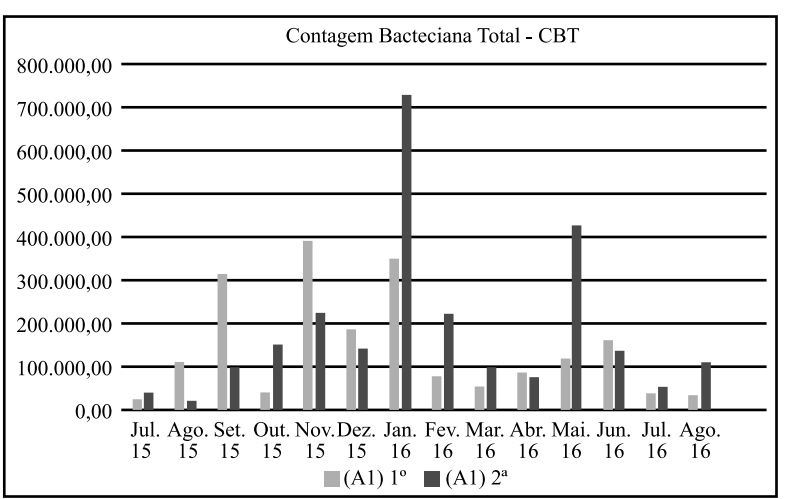

Figura 3 - Valores da contagem bacteriana (CBT) do agricultor (A3) antes e depois de usar o detergente alcalino e desinfetante à base de carqueja. Os valores referem-se à $1^{\mathrm{a}}$ e $2^{\mathrm{a}}$ análise/mês. Os valores são medidos em UFC/ ML X 1000

Os resultados obtidos através da avaliação da qualidade do leite nos meses de julho a dezembro de 2015, ou seja, período em que o agricultor (A3) utilizou o detergente comercial variaram de 25.000 a 392.000 UFC/ml. Já os resultados obtidos através da avaliação da qualidade do leite nos meses de janeiro a agosto de 2016, ou seja, período em que o agricultor utilizou o detergente alcalino e desinfetante à base de carqueja variaram de 34.000 a $729.000 \mathrm{UFC} / \mathrm{ml}$.

Na Figura 3 observa-se que das doze análises efetuadas nos meses de julho a dezembro de 2015, duas (2) ficaram acima de $300.000 \mathrm{UFC} / \mathrm{ml}$ de leite, representando 16,6\%. Na Figura 3 observa-se também que com a utilização do detergente comercial, das doze análises efetuadas, sete $(58,33 \%)$, apresentaram valores superiores a 100.000 
UFC/ml, e que após a utilização do detergente alcalino e desinfetante à base de carqueja, das 16 análises, oito (50\%) apresentaram contagem bacteriana acima de 100.000 UFC/ml. Constatou-se que durante todo o período de acompanhamento dos dados do referido agricultor, a CBT apresentou oscilações, com períodos de valores abaixo de $300.000 \mathrm{UFC} / \mathrm{ml}$, e períodos acima dos valores permitidos pela legislação. Muitos fatores podem estar influenciando estes resultados, estando entre estes, a qualidade da energia elétrica que abastece a propriedade, que é monofásica, e que poderia estar influenciando diretamente os resultados obtidos. Pois no momento da ordenha, o resfriador é desligado por um período de 90 minutos, em dois momentos do dia (manhã e noite). Neste período que o resfriador é desligado, o leite que vem diretamente da ordenhadeira em temperatura média de $37^{\circ} \mathrm{C}$ é adicionado aos demais litros já resfriados e não é homogeneizado pela falta de energia como preconiza a legislação. De acordo com Fonseca (1998), a temperatura e o período de tempo de armazenamento do leite também são importantes, uma vez que estes dois fatores estão diretamente ligados com a multiplicação dos microrganismos presentes no leite, afetando a contagem bacteriana total. Segundo Cerqueira (2007), a elevação da temperatura permite iniciar um novo ciclo de crescimento de microrganismo. Já Behmer (1999) afirma que em termos de refrigeração, deve-se ter como meta a obtenção do leite a uma temperatura de $4^{\circ} \mathrm{C}$ dentro de duas horas após a primeira ordenha. Já na segunda ordenha, nos casos em que se utiliza o sistema de tanque de expansão, a temperatura do leite de mistura não deve ultrapassar $7^{\circ} \mathrm{C}$ e deve voltar para $4^{\circ} \mathrm{C}$ dentro de uma hora após o término da ordenha. Sendo assim, o leite da segunda ordenha ao ser misturado ao da primeira ordenha, sem a devida homogeneização das quantidades, pode estar acarretando em aumento das bactérias.

Neste estudo observou-se que no mês de janeiro de 2016 dentre os três agricultores que utilizaram o detergente e desinfetante à base de carqueja, somente o agricultor (A3) apresentou resultados com contagem bacteriana elevada, sendo que na primeira amostra detectou-se 352.000,00 $\mathrm{UFC} / \mathrm{ml}$ e na segunda amostra $729.000 \mathrm{UFC} / \mathrm{ml}$, resultando em uma média de $540.000 \mathrm{UFC} / \mathrm{ml}$, ficando assim, acima do limite exigido pela legislação. Uma das hipóteses para explicar este resultado seria a temperatura inadequada da água $\left(60^{\circ}\right.$ graus) usada na limpeza da ordenhadeira. Após recomendações para uso da água com temperatura mais elevada, acima de $70^{\circ}$ graus, pode-se constatar queda considerável na contagem bacteriana nos meses subsequentes (Figura 3).
Na segunda análise dos meses de fevereiro, março e agosto de 2016, pode-se observar como consta na Figura 3 , que, mesmo que a CBT tenha ficado abaixo dos 300.000 $\mathrm{UFC} / \mathrm{ml}$, há uma disparidade muito grande em relação às duas análises efetuadas em cada mês, período este, em que foi realizada a segunda análise das amostras do leite. Neste sentido, acredita-se que a precipitação pluviométrica tenha influenciado no resultado, já que, no mês de fevereiro, dos dias 09 a 14, choveu aproximadamente 50 milímetros, enquanto que em março, nos dias 08 e 09 choveu aproximadamente 51 milímetros e, em agosto, choveu aproximadamente 35 milímetros na primeira quinzena.

Os resultados obtidos com o Agricultor testemunha $(\mathrm{T})$ podem ser visualizados na Figura 4.

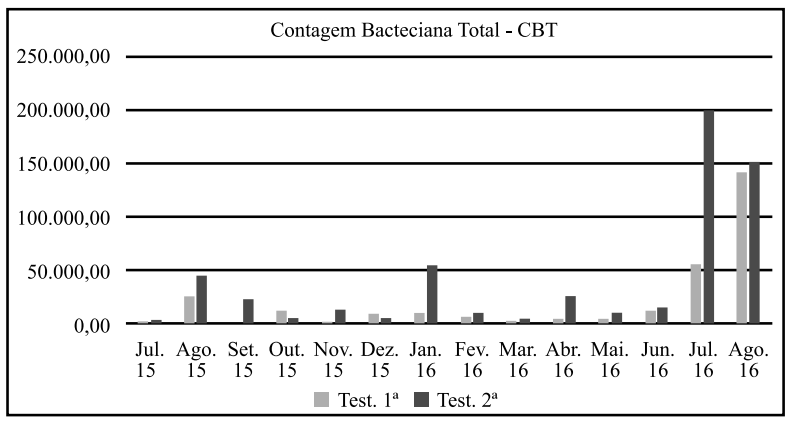

Figura 4 - Valores da contagem bacteriana (CBT) do agricultor (T) obtidos com o uso de detergente alcalino comercial. Os valores referem-se à $1^{\text {a }}$ e $2^{\mathrm{a}}$ análise/mês. Os valores são medidos em UFC/ML X 1000.

Os resultados obtidos através da avaliação da qualidade do leite nos meses de julho de 2015 a agosto de 2016, ou seja, período em que o agricultor (T) utilizou o detergente comercial variaram de 11.000 $\mathrm{UFC} / \mathrm{ml}$ a $1.998 .000 \mathrm{UFC} / \mathrm{ml}$ durante todo o período do acompanhamento dos dados. Na Figura 4, observa-se que das vinte e oito análises efetuadas nos meses de julho de 2015 a agosto de 2016, seis (21,42\%) ficaram acima de $300.000 \mathrm{UFC} / \mathrm{ml}$ de leite e das dezesseis análises feitas no ano de 2016, 57,14\% apresentaram valores superiores a $100.000 \mathrm{UFC} / \mathrm{ml}$.

$\mathrm{Na}$ Figura 4, pode-se observar que o agricultor intitulado como testemunha, enfrentou problemas quanto ao controle da CBT nos meses de julho e agosto. Baseado no relato do agricultor, dentre os fatores que podem ter influenciado os resultados, ele destaca a temperatura do leite 
no momento da coleta, a qual varia em aproximadamente $10^{\circ} \mathrm{C}$ no resfriador, pois o leite é carregado em um horário próximo ao horário da ordenha. De acordo com Brasil (2011), a IN 62 determina que a temperatura do leite chegue a $4^{\circ} \mathrm{C}$ no tempo máximo de 3 horas após o término da ordenha, pois, esta temperatura de armazenamento do leite pode inibir ou reduzir a multiplicação da maioria das bactérias e a ação de suas enzimas (Arcuri et al., 2006). $\mathrm{O}$ agricultor acredita que este não seja um bom horário para o carregamento, já que o leite ordenhado é misturado ao leite resfriado, não permitindo a redução suficiente da temperatura do mesmo até o momento do seu recolhimento. A legislação preconiza que, antes do início da coleta para análise, o leite deve ser agitado com utensílio próprio e ter a temperatura anotada (Brasil, 2011), o que entretanto, não tem como ser monitorado, de modo que não é possível afirmar se este procedimento foi ou não realizado no momento do recolhimento do leite realizado neste estudo. Segundo Brito et al. (2015), as mostras devem ser coletadas em recipientes apropriados, limpos e esterilizados e devem ser encaminhados ao laboratório a temperatura máxima de $7^{\circ} \mathrm{C}$, idealmente, em torno de $4^{\circ} \mathrm{C}$.

Com relação à $\mathrm{CBT}$ obtida através da utilização de detergentes comerciais convencionais e em relação ao uso do detergente alcalino e desinfetante à base de carqueja os resultados obtidos com todos os agricultores, ou seja, A1, A2, A3 e T podem ser visualizados nas Figuras 5 e 6.

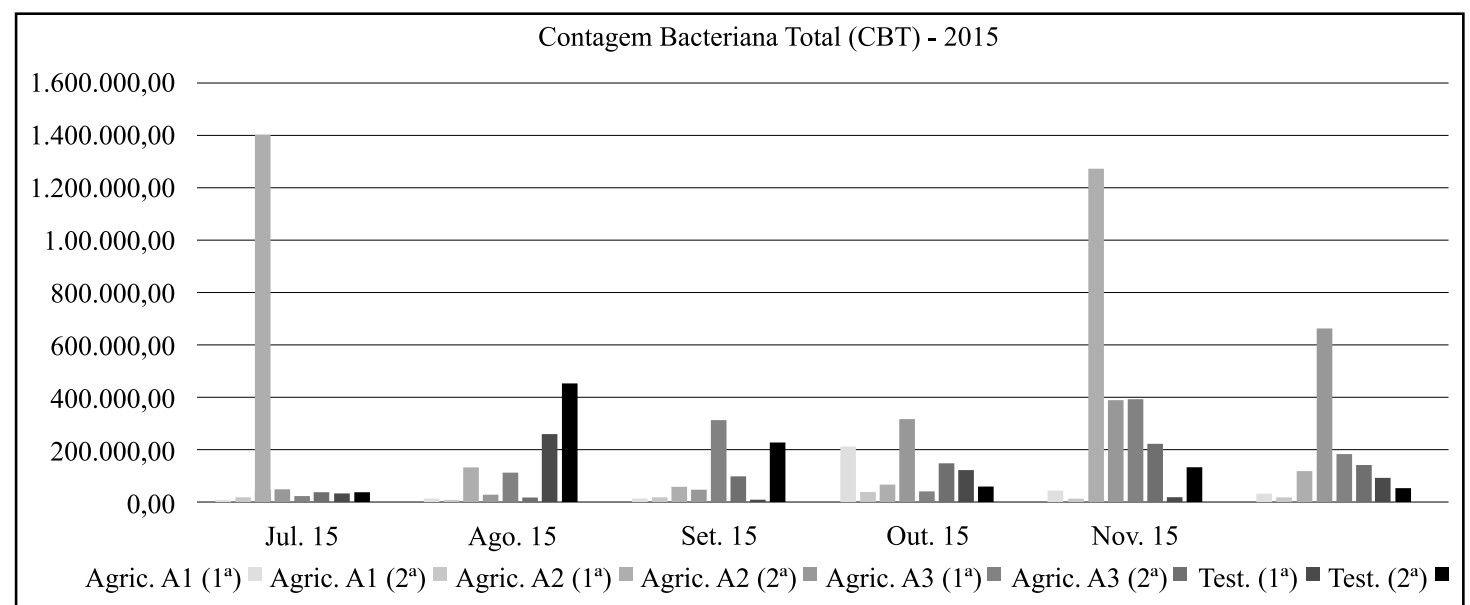

Figura 5 - Valores da contagem bacteriana (CBT) dos agricultores A1, A2 e A3 antes de usar o detergente alcalino e desinfetante à base de carqueja, além do agricultor testemunha que utilizou o produto comercial. Os valores referem-se à $1^{\mathrm{a}}$ e $2^{\mathrm{a}}$ análise/mês. Os valores são medidos em UFC/ML X 1000 .

Nas Figuras 5 e 6, observa-se com base nos resultados, que mesmo antes da adoção do uso do detergente alcalino à base de carqueja, as contagens bacterianas encontravam-se na maioria do período dentro dos padrões estabelecidos pelo MAPA, para os agricultores A1, A2 e A3. No período de julho a dezembro de 2015, foram 36 análises com o detergente alcalino convencional e destas, sete amostras ficaram acima de 300.000 UFC/ $\mathrm{ml}$ totalizando $19,44 \%$ e, 14 amostras ficaram acima de $100.000 \mathrm{UFC} / \mathrm{ml}$ totalizando $38,88 \%$. No período de janeiro a agosto de 2016, foram efetuadas 45 análises com o detergente alcalino e desinfetante à base de carqueja e quatro amostras ficaram acima de $300.000 \mathrm{UFC} / \mathrm{ml}$, totalizando $8,88 \%$ e, 17 amostras ficaram acima de $100.000 \mathrm{UFC} / \mathrm{ml}$, totalizando $37,77 \%$. Schuch et al. (2008) avaliaram extratos hidroalcóolicos (EHA) de folhas e talos de Baccharis trimera (carqueja), Eucalyptus ssp (eucalipto) e Tagetes minuta (chinchilo), como desinfetante/antiséptico na desinfecção do úbere de vacas pós-ordenha em comparação à Clorexidina, utilizada no experimento como controle $\mathrm{e}$ observaram que, a Clorexidina, foi capaz de inativar o estreptococos Streptococcus agalactiae em 30 segundos, a bactéria Pseudomonas aeruginosa em 2 minutos e a bactéria Staphylococcus aureus em 10 minutos. Em estudos realizados por Nascimento et al. (2014), os autores relatam que a utilização de produtos fitoterápicos no manejo pré e pós - dipping mostrou-se uma alternativa promissora para os produtores de leite que pretendem atender aos padrões de qualidade. Neste sentido, segundo Bevilaqua et al. (2015) a carqueja possui diversas propriedades 
fitoterápicas e medicinais, sendo utilizada na produção agropecuária como base para a preparação de produtos para limpeza e sanitização de materiais utilizados em pré e pós-ordenha de vacas leiteiras. Segundo os mesmos autores, essas propriedades antibióticas e antissépticas auxiliam na diminuição da população de microrganismos, tornando esses produtos naturais uma alternativa muito interessante para ser utilizada em propriedades rurais, visto ser uma planta relativamente comum e adaptada a diversas condições edafoclimáticas.

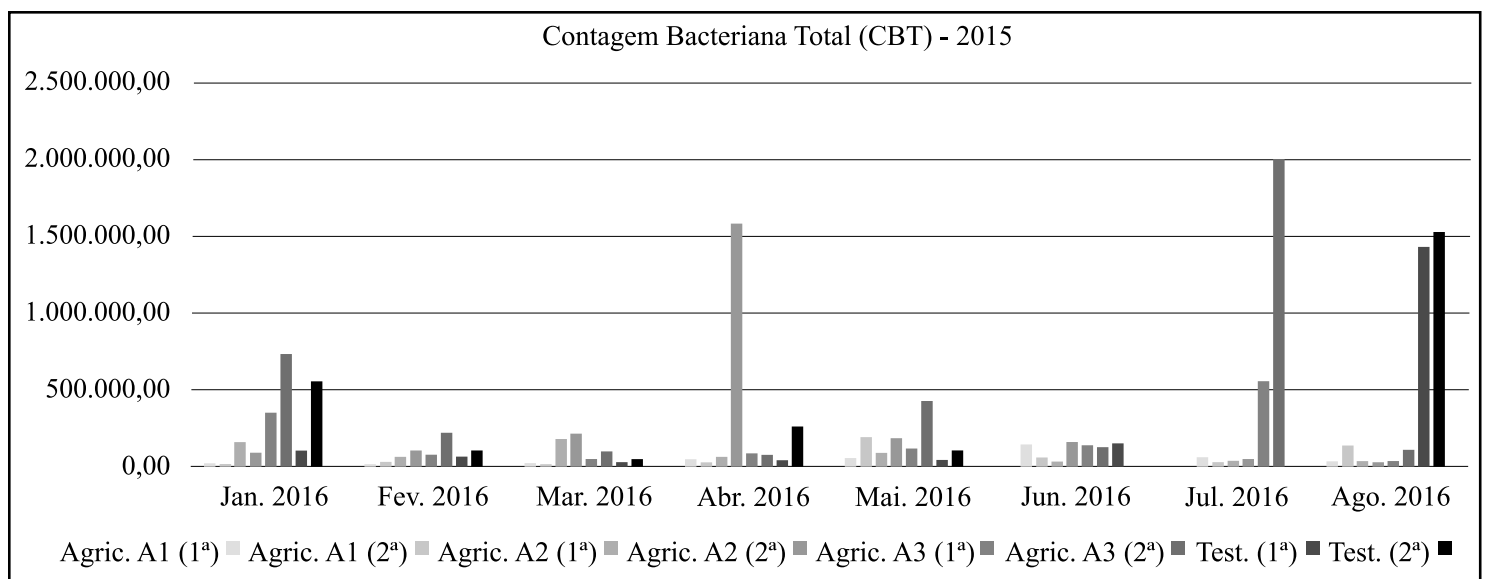

Figura 6 - Valores da contagem bacteriana (CBT) dos agricultores A1, A2, A3 depois de usar o detergente alcalino e desinfetante à base de carqueja, além do agricultor testemunha (T) que utilizou o produto comercial. Os valores referem-se à $1^{\mathrm{a}}$ e $2^{\mathrm{a}}$ análise/mês. Os valores são medidos em UFC/ML X 1000.

\section{CONSIDERAÇÕES FINAIS}

O uso de detergente a base de carqueja na sanitização de equipamentos de ordenha permite a obtenção de Contagem Bacteriana Total (CBT) em níveis inferiores ao que preconiza a legislação vigente em relação à qualidade do leite.

\section{LITERATURA CITADA}

ANDRADE, N.J.; PINTO, C.L.O. Higienização na indústria de alimentos. Viçosa: CPT, 1999.

ARCURI, E.F.; BRITO, M.A.V.P.; BRITO, J.R.F. PINTO, S.M.; ÂNGELO, F.F.; SOUZA, G.N. Qualidade microbiológica do leite refrigerado nas fazendas. Arquivo Brasileiro de Medicina Veterinária e Zootecnia, v. 58, p. 440-446, 2006.

AVANCINI, C.A.M.; WIEST, J.M.; MUNDSTOCK, E. Atividade bacteriostática e bactericida do decocto de Baccharis trimera (Less.) D.C., Compositae, carqueja, como desinfetante ou antisséptico. Arquivo Brasileiro de Medicina Veterinária e Zootecnia, v. 52, n.3, p. 230-234, 2000.

BAVA, L.; ZUCALI, M.; BRASCA, M.; ZANINI, L.; SANDRUCCI, A. Efficiency of cleaning procedure of milking equipment and bacterial quality of milk. Italian Journal of Animal Science, v. 8, n. 2, p. 387-389, 2009.

BEHMER, M.L.A. Tecnologia do leite. 13. ed. São Paulo: Noel, 1999.

BEVILAQUA, G.A.P. et al. Tecnologia de plantas medicinais e bioativas da flora de clima Temperado. Pelotas: EMBRAPA Clima Temperado, 2015. 100p.

BRASIL. Ministério da Agricultura, Pecuária e Abastecimento. Secretaria de Defesa Agropecuária. Instrução normativa $n^{\circ}$ 62, de 29 de dezembro de 2011. Regulamento Técnico de Produção, Identidade e Qualidade do Leite. Brasília, 2011. Disponível em: <http://www. apcbrh.com.br/files/IN62.pdf>. Acesso em: 05 set. 2018.

BRITO, J.R.F.; SOUZA, G.N.; FARIA, C.G.; MORAES, L.C.D.; RODRIGUES, M.C. Procedimentos para coleta $e$ envio de amostras de leite para determinação da composição e das contagens de células somáticas e de bactérias totais. Circular Técnica da Embrapa, Juiz de Fora, MG. 2015.

BUENO, V.F.F.; MESQUITA, A.J.O.; OLIVEIRA, A.N.; NICOLAU, E.S.; NEVES, R.B.S. Contagem bacteriana total do leite: relação com a composição centesimal e período do ano no Estado de Goiás. Revista Brasileira de Ciência Veterinária, v. 15, n. 1, p. 40-44, 2008. 
CERQUEIRA, M.M.O.P. Qualidade da água e seu impacto na qualidade microbiológica do leite. Revista Leite Integral, v. 7, p. 54-61, 2007.

FONSECA, L.F.L. Qualidade do leite e sua relação com equipamento de ordenha e sistema de resfriamento. In: SIMPÓSIO INTERNACIONAL SOBRE QUALIDADE DO LEITE, n. 1. Curitiba, 1998.

GARCIA, O.J.P.; LUNARDI, J. Práticas alternativas de prevenção e controle das doenças dos bovinos. Porto Alegre: EMATER-RS/ASCAR, 2001.

GLIESSMAN, S.R. Agroecologia: processos ecológicos em agricultura sustentável. 2. ed. Porto Alegre: UFRGS, 2000. 653p.

HOFFMANN, F.L.; COELHO, A.R.; MANSOR, A.O.; VINTURIM, T.M. Avaliação da atividade antimicrobiana "in vitro" de dois agentes sanificantes de uso industrial. Higiene Alimentar, v. 16, n. 94, p. 62-67, 2002.

IBGE - INSTITUTO BRASILEIRO DE GEOGRAFIA E ESTATÍSTICA. Indicadores: estatísticas de produção pecuária. Brasília, 2014. Disponível em: <http://www.ibje. org.br/pdf $>$. Acesso em: 05 set. 2018.

KARAM, T.K.; DALPOSSO, L.M.; CASA, D.M.; FREITAS, G.B.L. Carqueja (Baccharis trimera): utilização terapêutica e biossíntese. Rev. Bras. Plantas Med., Botucatu, v. 15, n. 2, p. 280-286, 2013.

LEITE, M.O.; ANDRADE, N.J.; SOUZA, M.R.; FONSECA, L.M.; CERQUEIRA, M.M.O.P.; PENNA, C.F.A.M. Controle de qualidade da água em indústrias de alimentos. Revista Leite e Derivados, v. 69, p. 01-06, 2003.

LORENZI, H.E.; MATOS, F.J.A. Plantas medicinais no Brasil: nativas e exóticas. 2. ed. São Paulo: Instituto Plantarum, 2002. 512p.

MARTINS, M.C. Competitividade da cadeia produtiva do leite no Brasil. Revista de Política Agrícola, n. 3, p. 38-51, 2004.
MENDONÇA, L.C.; GUIMARÃES, A.S.; BRITO, M.A.V.P. Higienização do equipamento de ordenha mecânica. Circular Técnico da Embrapa, Juiz de Fora, MG. 2012.

NASCIMENTO, G.C., COSTA, L.C.; MORAIS, C.O.; ROSCOE, A.C.; TEIXEIRA, R.B.; NORONHA, C.M.S. Fitoterápicos no manejo pré e pós - dipping de bovinos de leite. VII Semana de Ciência e Tecnologia IFMG - campus Bambuí VII Jornada Científica e I Mostra de Extensão. Out. de 2014. Disponível em: https://www.bambui.ifmg. edu.br/jornada_cientifica/2014/resumos/Zootecnia/Fitoter\%C3\%A1picos\%20no\%20manejo\%20pr\%C3\%A9\%20 e $\% 20$ p $\%$ C3\%B3s $\% 20 \%$ E2\%80\%93\%20dipping $\% 20$ de\%20bovinos\%20de\%20le.pdf. Acesso em: 16 jan., 2016.

SANTOS, A.A.M.; VEROTTI, M.P.; SANMARTIN, J.A.; MESIANO, E.R.A.B. Importância do álcool no controle de infecções em serviços de saúde. Revista de Administração em Saúde, v. 4, n. 16, p. 7-14, 2002.

SANTOS, M.V.; FONSECA, L.F.L. Estratégias para o controle de mastite e melhoria da qualidade do leite. São Paulo: Manole, 2007. 314p.

SCHUCH, L.F.D.; WIEST, J.M.; COIMBRA, H.S. Cinética da atividade antibacteriana in vitro de extratos naturais frente a microrganismos relacionados à mastite bovina. Ciência Animal Brasileira, v.9, n.1, p. 161-169, 2008.

VELlOSO, C.C.; PEGLOW, K. Plantas medicinais. Porto Alegre: EMATER-RS/ASCAR, 2003. 83p. (Coleção Aprendendo a Fazer Melhor).

ZUCALI, M.; BAVA, L.; TAMBURINI, A.; BRASCA, M.; VANONI, L.; SANDRUCCI, A. Effects of season, milking routine and cow cleanliness on bacterial and somatic cell counts of bulk tank milk. Journal of Dairy Research, v. 78, p. 436-441, 2011.

Recebido para publicação em 24/05/2019 e aprovado em 20/12/2019. 